\title{
Bank Insolvencies, Priority Claims and Systemic Risk
}

\author{
Spiros Bougheas \\ School of Economics, University of Nottingham
}

Alan Kirman

GREQAM, EHESS, Aix-Marseille University, France

September 2015

\begin{abstract}
We review an extensive literature debating the merits of alternative priority structures for banking liabilities put forward by financial economists, legal scholars and policymakers. Up to now, this work has focused exclusively on the relative advantages of each group of creditors to monitor the activities of bankers. We argue that systemic risk is another dimension that this discussion must include. The main message of our work is that when bank failures are contagious then when regulators assign priority rights need also to take into account how the bankruptcy resolution of one institution might affect the survival of other institutions that have acted as its creditors. When the network structure is fixed the solution is straightforward. Other banks should have priority to minimize the risk of their downfall. However, if the choice of policy can affect the structure of the network, policy design becomes more complex. This is a fruitful avenue for future research.
\end{abstract}

Keywords: Banks; Priority rules; Systemic Risk

JEL: G21, G28 


\section{Introduction}

There is a hierarchy among a firm's creditors that is relevant when the firm becomes insolvent. The hierarchy reflects the allocation of priority rights among the creditors such that those higher in the hierarchy are paid in full before any other parties below receive any compensation. ${ }^{1}$ This differential protection offered by the allocation of property rights has been designed to optimize the ability of the firm to raise funds from financial markets. Since the 2008 global financial crisis there has been a lot of interest in the design of bankruptcy resolution procedures and priority rules for banks. ${ }^{2}$ What is striking is the large variety of both bankruptcy procedures (Berkovitch and Israel, 1999) and priority rules applied across the globe (Lenihan, 2012; Wood, 2011). Some countries have had for some time some form of depositor preference rule (e.g. Australia, Switzerland and United States). Other countries have either only recently introduced or are in the process of introducing such rules. These include Greece, Portugal, Hungary, Latvia and Romania that have to implement such rules as part of the conditions that they need to meet in order to participate in EU/IMF programmes. In the UK the Vickers report recommends the introduction of a depositor preference rule (ICB Report 2011).

Most of the arguments offered for the support of proposals concerning priority rules are based on the incentives that these rules provide to depositors and other creditors to monitor the activities of bank managers. However, as Dewatripont and Freixas (2012) point out bankruptcy rules that might be optimal responses to individual bank failures might not be efficient when the crisis is systemic. In particular, they observe that adequate liquidity provision to solvent institutions might be sufficient to avert contagion throughout the system in the case of a single bank failure but not so during a systemic crisis. In the latter case, liquidity shortages and the depression of asset prices used as collateral (fire sales) might demand support for both solvent and insolvent institutions.

In this paper we review various arguments put forward by both economists and legal scholars supporting either existing or new proposals for priority rules in banking. Our main focus is on the relative positions on the ladder of depositors and other financial institutions linked through the interbank market. In our review we include both theoretical arguments and related empirical evidence. Reading this literature we were surprised by the absence of any arguments related to systemic risk issues. In the penultimate section of the paper we argue that the choice of priority rules can have considerable implications for the propagation of failures across the financial system.

\footnotetext{
${ }^{1}$ There is an extensive literature in financial economics that studies the optimal design of bankruptcy procedures; see von Thadden et al. (2010) for a recent review of the relevant literature.

${ }^{2}$ See Walter (2004) for a description of the actuall process of bankruptcy resolution followed in US during the financial crisis.
} 


\section{Priority Rules in Practice}

As we indicated above there are variations in bankruptcy procedures and rules applied around the globe. To focus the discussion we begin by taking a close look at one such priority structure, namely, that of US bank balance sheets as presented in Wood (2011).

1. Super-priority creditors (secured creditors)

(a) creditors with security interests over collateral

(b) sale and repurchase agreements (repos)

2. Priority creditors
(a) retail depositors
(b) life/pension insurance claimants
(c) employee remuneration and benefits
(d) unpaid taxes

3. Pari passu creditors
(a) banks
(b) bondholders

4. Subordinated creditors (tier structure)
(a) senior subordinated
(b) junior subordinated
(c) preferred shares

5. Equity shareholders

6. Expropriated creditors

(a) foreign currency creditors

Right at the top of the list (most senior instruments) we find contracts secured by collateral. During systemic events it is the collapse of the prices of the underlying assets pledged as collateral that dries up the liquidity of the financial system. Before the 2008 financial crisis many banks had pledged as collateral very similar assets created though the securitization of mortgages. One of the causes of the crisis has been the enhanced uncertainty that surrounded the valuation of these assets. As some institutions attempted to obtain liquidity by selling these assets, they drove their prices down, directly affecting the value of collateral pledged by other institutions. This led to further drops in prices (fire sales). This phenomenon has been extensively researched in recent years and 
also lies behind the Dewatripont and Freixas (2012) argument for a differential treatment of failing banks during a systemic crisis. ${ }^{3}$ In case of insolvency, assets not pledged as collateral will be distributed to other creditor following the above seniority structure.

What is most relevant for our purposes is the relative positions of retail depositors and banks. The 'banks' entry in the above table mainly captures transactions in the interbank market (loans of durations from one day to three months). The interbank market provides the links that connect the banking network. The severity, in terms of aggregate losses, of a financial crisis depends on the exact structure of the network and the magnitude of initial losses. There is an extensive literature studying the structure of such a network and its implications for systemic risk. ${ }^{4}$ While the relationship between connectedness and systemic risk is complex some general patterns have been identified: for example, for low values of initial losses a higher degree of connectedness is good news as the losses are spread out and thus the impact on any particular institution is minimized; in contrast, when initial losses are large a high degree of connectedness can be harmful as it increases the likelihood of multiple failures (see Acemoglu et al., 2015a).

The particular structure shown above reflects the enactment by the US Congress of the 1991 Federal Deposit Insurance Corporation Improvement Act that was followed by the 1993 Depositor Preference Act. Both acts were part of the policy response to the 1980s Savings and Loans crisis. The purpose for introducing the 1991 Act was to shift some of the risk of bank failures away from taxpayers and uninsured depositors and more to other creditors thus reducing the cost of federally provided insurance. Similar concerns led to the introduction of explicit rules in the Single Resolution Mechanism specifying ptotective measures for the depositor guarantee scheeme. ${ }^{5}$ Thus, deposits are senior to bonds and interbank market loans which, in turn, are senior to subordinated debt. ${ }^{6}$ As we observed earlier, the above structure is not universal and the relative positions of uninsured depositors and other creditors varies from country to country.

There is a variety of both theoretical and informal arguments that have been advanced in support of various priority rules.

\footnotetext{
${ }^{3}$ For a general analysis, see Shleifer and Vishny (1992). More recently, this work has been applied to banking to explain fire sales, market freezes, market spirals and related phenomena (see, for example, Acharya et al., 2011; Bebchuk and Goldstein, 2011; Brunnermeier and Pedersen, 2009; Caballero and Simsek, 2013; Diamond and Rajan, 2011) For a more thorough review of this literature, see Shleifer and Vishny (2010).

${ }^{4}$ For reviews of the literature see Allen and Babus (2009) and Bougheas and Kirman (2015a).

${ }^{5}$ See Regulation (EU) No 806/2014 of the European Parliament Council of July 2014. http://eur-lex.europa.eu/legal-content/EN/TXT/?uri=CELEX:32014R0806

${ }^{6}$ By tier structure we imply that the entries under subordinated debt are also ordered according to seniority.
} 


\section{Theoretical Arguments}

There is a long debate about whether uninsured depositors have the incentives to monitor the activities of banks. ${ }^{7}$ Calomiris and Kahn (1991) have argued that by its very nature demandable debt (demand deposits), that allows depositors to withdraw their funds at will, offers the required market discipline device. As Diamond and Dybvig (1983) have shown the role of demand deposits is to provide insurance to depositors against indiosyncratic liquidity risk. More specifically, the contract offers risk-averse depositors flexibility with the timing of their withdrawals while at the same time allows banks to invest in long-term illiquid projects. However, inherent in the design is the possibility of a bank run where all depositors withdraw their funds at the same time. These runs are not only rational, given the beliefs that each depositor holds about the actions of other depositors, but can also be ex ante optimal (Allen and Gale, 2007). That is the decision of depositors to trust their funds to banks can be ex ante efficient as long as the probability of runs is relatively small. Runs in the Diamond and Dybvig (1983) framework are pure sunspot phenomena. Put differently, they arise as because of coordination failures and it is not clear why in such environments depositors would be appropriate monitors. However, Jacklin and Bhattacharya (1988) allow the investment of banks to be risky and show that widespread runs can be generated by a small number of informed depositors who receive early signals about the bank's performance. It seems in that model informed depositors are performing the monitoring role.

Rochet and Tirole (1996) offer support for the argument that the most suitable monitors for banks are other banks and therefore interbank loans should be junior to deposits. They argue that interbank exposures generated through transactions in the interbank market provide strong incentives for banks to monitor other banks. ${ }^{8}$ Clearly, the effectiveness of such incentives would depend on whether or not banks believe that the government will intervene in their favour during a crisis. If they believe that the government is likely to come to the rescue, of at least large institutions, then they might consider that some transactions in that market do not bear any risk. Since the 1998 global financial crisis a growing literature is attempting to address the vulnerability of financial systems to institutions that are 'Too-Big-To-Fail' (Kaufman, 2014).

Along similar lines, Birchler (2000) has argued in favor of depositor preference on the grounds that other creditors, like banks, have an informational advantage relative to a large number of small depositors. ${ }^{9}$ Moreover, he argues that offering a standardized product to depositors with priority rights is

\footnotetext{
${ }^{7}$ Beyong their effects on the incentives to monitor, changes in priority rules can have other consequences. Such changes would affect the prices of those claims whose priority has been affected, potentially changing their ownership and thus the entities affected in the case of bankruptcy (see Danisewicz et al., 2015).

${ }^{8}$ Their argument bears some similarity to the one used for supporting the seniority of bank claims on the balance sheets of other firms (see Longofer and Santos, 2000).

${ }^{9} \mathrm{His}$ work is an application to banking of earlier theoretical work on the role of seniority on corporate balance sheets (see, for example, Diamond, 1993; Hart and Moore, 1995).
} 
a more efficient way of raising funds than having each depositor sign a bilateral contract with a bank. Therefore, his framework explains why the balance sheets of borrowers include a whole variety of debt instruments that differ according to their seniority status. The introduction of a priority list reduces the amount of resources devoted to socially inefficient information gathering. Such an arrangement it seems is ideal for banks that raise funds from a large number of uninformed investors.

While each of the above studies clearly supports either depositor or bank preference, Freixas, Rochet and Parigi (2004) offer a more mixed view. In their model banks provide two types of services. They screen potential applicants thus improving the pool of loans that they offer and monitor firms that receive loans to ensure they perform well. Banks are subject to both liquidity and solvency shocks. The role of the interbank market is to redistribute funds from liquid to illiquid institutions, however, insolvent institutions cannot be prevented from using the market to gamble for resurrection. The optimal seniority status of interbank market loans depends on which of the two moral hazard problems associated with two services provided by banks is the most severe. When market discipline is weak then monitoring services become important. In this case, the only banks that seek funds from the interbank market are those that are illiquid and solvent banks and should not be penalized by excessive risk premia. Thus, it is optimal that interbank market loans are either secured or senior to other claims. In contrast, when the screening constraint binds then the interbank market loans cannot be secured and the premia must reflect the cost of insolvency.

The majority of studies that analyze the seniority structure of bank loans focus on the interbank market where loans are not secured. However, on the liability side of the balance sheets of banks we find other claims by financial institutions that are secured and therefore occupy the top step in the hierarchy ladder. Bolton and Oehmke (2015) analyze the seniority status of derivatives. They conclude that while these claims enhance value by providing risk management solutions, their seniority status can lead to inefficiencies as it transfers risk to other liabilityholders, such as depositors.

Lastly, there are also studies arguing that the most suitable monitors of bank activities are subordinated debtholders. The idea is that the market will provide the discipline required for reducing risk taking activities. ${ }^{10}$ Theoretical work by Blum (2002) sheds some doubt about the efficacy of this policy. Requiring banks to hold some prespecified amount of subordinated debt may not prevent banks from pursuing high-risk activities and even worse might induce them to undertake even higher-risk activities. The reason is that protection by limited liability offers incentives to banks to decrease the cost of debt by increasing the amount of their borrowing as soon as the interest rate is fixed by the market. Thus there is a trade-off between the benefits derived from obtaining information about what banks do and the costs associated with the increase in balance sheet risk.

${ }^{10}$ See Evanoff (1993) and Herring (2004) for support of this view. 
At this point we notice that, with the one exception the work by Rochet and Tirole (1996), research in this area does not directly address the issue of contagion.

\section{Informal Arguments}

Overall, the types of arguments that have been offered in favour of one priority rule over another follow the theoretical literature discussed above by advocating that the party most suited to monitor the activities of banks should be relatively low in the priority hierarchy. This particular debate has focused on five types of bank creditors: insured depositors, uninsured depositors, international depositors, other banks and subordinated debtholders. However, there are many researchers and legal scholars who put more emphasis on the implementation of rules arguing that often preference rules have unintended consequences.

Among domestic depositors only those with uninsured claims have an incentive to monitor their banks. ${ }^{11}$ Do they do it? The evidence is mixed. Jordan (2004) studying a sample of banks that failed in New England during the 1990s finds that uninsured depositors respond to bad news. At times these depositors not only react in a severe fashion but also start as early as two years before the bank is closed. The author concludes that the ability of banks to raise funds in the insured deposit market delays the closure of banks by dampening the effects due to the actions of uninsured depositors. A similar conclusion is reached by Billett, Garfinkel, and O'Neal (1998) who analyzed announcements of credit rating changes for bank holding companies (BHCs) for the period January 1990 through December 1995. They find that banks increase their use of insured deposits after they have been downgraded by Moody's. Thus they conclude that an increase in the interest rate that they have to pay to attract uninsured deposits, or even the withdrawal of uninsured deposits, may not have a significant effect on banks' risk taking decisions.

Other scholars have warned about unintended consequences of depositor preference rules. For example, Kaufman (1997) criticizing the 1993 Depositor Preference Act observed that depositor priority rules can be circumvented by nonpreferred claimants who effectively become preferred claimants when the borrower secures their funding by offering them collateral. ${ }^{12}$ Thomson (1994) and Marino and Bennett (1999) have argued that while the regulation seems to have worked with small bank failures it had unintended consequences with troubled larger institutions. Because the latter have a higher proportion of unsecured and international deposits, they faced a greater risk from the actions of those parties' national governments to protect them. ${ }^{13}$

Concerns have also been expressed more recently by Partnoy and Skeel (2007) and Perotti (2010) in response to bankruptcy privileges granted in 2005

\footnotetext{
${ }^{11}$ See Mantripragada (1992) for support of this view from a legal perspective.

12 There is a similarity between this argument and the theoretcal argument put forward by Bolton and Oehmke (2015) related to the role of derivatives.

${ }^{13}$ The 1993 Act placed international deposits very low on the priority ladder
} 
in both the US and Europe to overnight secured credit and derivatives that have effectively allowed these lenders to claim priority over all other creditors in case of default. They assert that while such regulations reduce considerably the cost of borrowing at the same time they eliminate all the incentives the privileged creditors have to monitor the borrowers. In times of financial trouble these are the creditors who keep providing funds to stressed institutions exactly because the last minute loans that they offer are secured. Along the same lines Hirschhorn and Zervos (1990) argue that if a large enough proportion of nondepositor claims becomes secured, depositor preference could increase the cost of bank failures to the deposit insurance agency. Their empirical analysis indicates that depositor preference will lead to a considerable increase in collateralization thus taking away funds during a resolution that would have been available for distribution to depositors..

As we have already observed unintended consequences are also associated with proposals aiming to delegate the monitoring role to subordinated debtholders. The evidence comes primarily from comparing yields of subordinated bonds and the performance of the issuing banks and, once more, is mixed (see Evanoff and Wall, 2002; Flannery and Sorescu, 1996; Goyal, 2005; Hancock and Kwast, 2001; Sironi, 2003).

Lastly, we turn our attention to the interbank market that is the main focus of our work. Evidence about the monitoring role played by creditors in this market comes from Furfine (2001) who collected every Fedwire funds transfer made during the first quarter of 1998. The main empirical findings of this study are: (a) banks with higher profitability, higher capital ratios, and fewer problem loans are charged lower interest rates on federal funds loans, and (b) larger institutions have an advantage as they pay lower interest rates on borrowed funds and charge higher interest rates on their loans. The evidence seems to suggest that banks can efficiently monitor other banks, however, there are also some potential problems. Firstly, the advantage of larger banks is consistent with the belief that these banks are 'Too-Big-To-Fail'. Secondly, the rates reflect only counterparty risk. Thirdly, the study was conducted during a calm period in financial markets. Taken together these three arguments raise concerns about the ability of banks to monitor themselves during systemic events.

\section{$5 \quad$ Priority Claims and Systemic Risk}

The literature on the optimal design of the priority structure of banking liabilities has exclusively focused on the incentives that alternative structures provide for risk taking and monitoring at the institutional level. As a consequence, the main arguments put forward are based at the relative abilities of various creditors to monitor the activities of bank managers. However, we argue that given the interconnectedness of the banking system, restricting the scope of the design at the institutional level might be potentially socially harmful. Cross-banking exposures through the interbank market imply that a failure of one institution can harm other directly linked institutions potentially leading to a cascade of 
failures throughout the system. In general, the level of systemic risk (potential aggregate losses) is not independent of the priority structure of bank liabilities. ${ }^{14}$ In order to keep the argument as simple as possible, in what follows, we are going to ignore all other reasons for generating a priority structure mentioned above and concentrate on systemic risk. Therefore, we will concentrate on total losses ignoring their division between depositors and bank equityholders. In fact, from a welfare point of view we need to compare total losses. There might be strong arguments to protect depositors (this can be the case, for example, if the goal is to protect the intermediation process by ensuring that depositors trust their savings with the financial system) but in such cases there are other instruments (e.g. deposit insurance) that can be employed to address such objectives.

For our analysis we consider a network of banks linked through the interbank market. Table 1 show a typical bank's balance sheet.

\begin{tabular}{ll}
\multicolumn{2}{c}{ Table 1: Bank Balance Sheet } \\
Assets & Liabilities \\
$L^{F}:$ Loans to firms & $D^{H}$ : Deposits by households \\
$L^{B}:$ Loans to other banks & $D^{B}$ : Deposits by other banks \\
$R:$ Reserves & $E:$ Equity
\end{tabular}

The entries $L^{B}$ and $D^{B}$ correspond to the links of the network. As it turns out our main arguments do not depend on the exact structure of the interbank network. However, it is important to keep in mind that the sum of all the interbank loans across the banking system is equal to the sum of all deposits by other banks across the banking system. Equity is defined as $E \equiv L^{F}+$ $L^{B}+R-D^{H}-D^{B}$. As long as $E \geqslant 0$ the bank is solvent. However, when $E<0$ the value of the assets falls below the value of liabilities and the bank becomes insolvent. In the latter case, the bankruptcy procedure will decide the division of assets among the bank's liabilityholders. In particular, a bankruptcy procedure specifies rules to allocate the remaining assets to the failing bank's liabilityholders, in our case, other banks and depositors. ${ }^{15}$ There are two broad rules that every bankruptcy procedure must satisfy:

Definition 1 Priority Rules: They specify a hierarchy among creditors such that in liquidation a group of creditors must be satisfied in full before any other group of creditors lower in the ladder receive any payments.

Definition 2 Pro-Rata Rule: All creditors belonging, according to priority rules, to the same level are compensated proportionately to the amount of their individual claims.

\footnotetext{
${ }^{14}$ Our analysis might also be relevant for other sectors of the economy as interconnectedness is not an exclusive feature of the financial system. Foe example, Acemoglu et al. (2015b) study how interindustry input-output linkages can magnify small idiosyncratic shocks to produce macroeconomic tail risk. But this is attributed to the fact that they observe the emergence of a strongly skewed distribution of firm sizes. They argue as did Gabaix (2011) that a small shock to a large firm can produce major events. To do the same here would require considering also the size distribution of banks and their place in the network.

${ }^{15}$ Actual capital requirement regulations imply that there will be regulatory intervention as soon as equity falls below a prespecified threshold.
} 
Given that our main interest is in understanding the relationship between priority rules and systemic losses, in the following discussion, we treat each group as a single agent.

We consider a bank that has to write-off some of its loans to firms and we assume that these losses are higher than the value of its equity so that the bank becomes insolvent. We would like to figure out how alternative priority rules affect not only losses born by the liability holders of the failing bank but also by the liability holders of other affected banks. The structure of the interbank network will determine which banks will be affected but this will not have any effect on our results. As we explained above, in terms of social welfare, ultimately what matters are the total losses to depositors and equityholders throughout the banking system.

Dividing the failing bank's loans to other banks, $L^{B}$, among its liabilityholders is, in principle, straightforward. These loans represent deposits of the failed bank at other banks and they can be reallocated at full value. However, the allocation of loans to firms, $L^{F}$, and reserves, $R$, where the latter might include a variety of assets differing to their degree of market liquidity, might be problematic. As we explained above these two groups of assets might have to be liquidated at depressed market prices below corresponding book values (fire sales) further magnifying initial losses. Let $l$ denote the fraction of the book value of assets recovered by liquidation (for simplicity we assume that is the same for all assets) and $V(>E)$ the value of loans written-off.

We are going to consider two cases. Firstly, we are going to analyze the model for the case when book and market values are the same. Put differently, we will ignore fire sales. For this case will show that priority rules do not matter. Then, we will introduce fire sales and show that the choice of priority rules can affect the magnitude of welfare losses due to systemic events.

\subsection{No Fire Sales}

We first consider the case when $l=1$ (no fire sales). Then the total losses suffered by depositors and other banks is equal to $V-E$. The exact division of these losses between the two groups of liabilityholders will depend on the priority rule. Let $x \in[0,1]$ denote the fraction of these losses born by depositors. Therefore, the total losses for the failing bank are equal to $E+x(V-E)$. The analysis of what happens with other affected banks who were creditors of the failing bank and those who were affected because of subsequent failures is greatly simplified by the existence of a unique clearing vector of payments that settles the obligations of all members of the banking system (see Acemoglu et al., 2015a; Eisenberg and Noe, 2001). This important result implies that our main conclusions follow directly from what we know about the bank that failed originally. The total losses of the banks that were direct creditors to the failing bank due to this first round of liquidation are at most equal to $(1-x)(V-E)$. If the losses are equal to the last expression implies that this second round of liquidations was sufficient to absorb the losses. Clearly, the losses were born by their equityholders and maybe, depending on the priority rule, also by their 
depositors. If, in contrast, some of the losses were absorbed by other banks then the process is repeated. Notice that some banks that survived earlier rounds of liquidations might not do so in subsequent rounds. What it is clear is that at the end of the clearing process the total losses will be equal to $V$ that is equal to the initial losses. Clearly, total losses are independent of the structure of the network and the priority rules of bankruptcy. However, the priority rules matter for the division of these losses between depositors and equityholders.

Proposition 1 In the absence of fire sales neither the structure of the interbank network nor the priority rules matter for total losses. Priority rules matter for the division of losses between depositors and equityholders.

\subsection{Fire Sales}

Next, we consider what happens when $l<1$ (fire sales). In the following analysis we assume that the network structure is independent of the priority rule. Our only objective in this paper is to show that the design of priority rules has potentially serious implications for the magnitude of systemic losses. Nevertheless, a complete analysis needs to consider that the choice of priority rules might affect the formation of the interbank network.

For the moment we focus on the bankruptcy procedure of the initial failing bank ignoring any subsequent rounds. ${ }^{16}$ The post-liquidation value of the failing bank's assets is equal to $L^{B}+l\left(R+L^{F}-V\right)$. Notice that the losses are equal to $(1-l)\left(R+L^{F}-V\right)$ and are decreasing in $l$. Clearly, the losses borne by other banks are greater under depositor priority. This matters for the value of total losses of the financial system because of fire sales. The higher the losses borne by banks the higher the probability that other banks will become insolvent and the higher the value of total losses given that liquidations are costly. Now, the structure of the financial network matters for the value of total losses, however, for a fixed network structure the value of total losses is higher under depositor priority. The following Proposition summarizes.

Proposition 2 Suppose that the formation of the banking network is independent of the structure of priority rules. Then, when liquidation is costly (fire sales) the value of total losses under depositor priority is at least as high as the total losses under bank priority.

The intuition is straightforward. When bank claims are senior to depositor claims the likelihood of further liquidations declines. When liquidation is costly (fire sales) the total losses of the banking system increase with the number of failing banks.

While the above analysis is too simplistic, as it ignores the incentives that priority structure offer for creating links in the network as well as the incentives that priority rules offer to different parties to monitor the bank's activities,

\footnotetext{
${ }^{16}$ The existence and uniqueness of the clearing vector is not violated when $l<1$, see Acemoglu et al. (2015a).
} 
we hope that it makes clear that ignoring systemic risk considerations when designing policy rules might be unwise.

\section{Conclusion}

The recent global financial crisis has made it painfully clear how important the design of the regulatory framework, that encompasses both rules and institutions, is for reducing the economy-wide losses associated with systemic events. ${ }^{17}$ We have argued that we need to consider carefully those rules that allocate priority rights among the various groups of bank creditors. There is an ongoing literature on this subject, however, it has mainly been concentrated on single bank resolutions rather than systemic events. The choice of priority rules can have a considerable effect on the total losses in the economy due to a systemic event. We have demonstrated how important this choice is for the simple case where the network structure is unaffected by the choice of priority rules. Future research should aim to explore this issue for the case when the interbank network is endogenous. It might be very well the case that when we allow for the choice of priority rues to affect the formation of links in the interbank market, our simple results above do not hold anymore. If different prioroty rules encourage or discourage certain entities from investing in the assets of certain others then rather than monitoring when faced with an enhanced risk, banks may prefer to invest elsewhere. While to analyse this might be a formidable task, given its significance for systemic risk policy design, cannot be ignored. ${ }^{18}$

\section{References}

[1] D. Acemoglu, A. Ozdaglar, A. Tahbaz-Salehi, 2015a. Systemic risk and stability in financial networks. American Economic Review 105, 564-608

[2] D. Acemoglu, A. Ozdaglar, A. Tahbaz-Salehi, 2015b. Microeconomic origins of macroeconomic tail risks. NBER Working Paper No. 20865

[3] V. Acharya, D. Gale, T. Yorulmazer. 2011. Rollover risk and market freezes. Journal of Finance 66, 1177-1209

[4] F. Allen, A. Babus, 2009. Networks in finance. In P. Kleindorfer, Y. Wind, R. Gunther (eds) The Network Challenge:Strategy, Profit, and Risk in an Interconnected World. Pearson Education, New Jersey, p. 367-382

[5] F. Allen, D. Gale, 2007. Understanding Financial Crises. Oxford University Press, New York

\footnotetext{
${ }^{17}$ This has also implications for the design of monetary policy. The Federal reserve in its attempt to provide liquidity to troubled institutions had to implement a number of nontraditional policies with unknown long-term consequenses (Cecchetti, 2008).

${ }^{18}$ See Bougheas and Kirman (2015b) for some preliminary work in this direction.
} 
[6] L. Bebchuk, I. Goldstein, 2011. Self-fulfilling credit market freezes. Review of Financial Studies 24, 3519-3555

[7] E. Berkovitch, R. Israel, 1999. Optimal bankruptcy laws across different economic systems. Review of Financial Studies 12, 347-377

[8] M. Billett, J. Garfinkel, E. O'Neal, 1998. The cost of market versus regulatory discipline in banking. Journal of Financial Economics 48, 333-58.

[9] U. Birchler, 2000. Bankruptcy priority for bank deposits: A contract theoretic explanation. Review of Financial Studies 13, 813-840

[10] J. Blum, 2002. Subordinated debt, market discipline, and banks' risk taking. Journal of Banking and Finance 26, 1427-1441

[11] P. Bolton, M. Oehmke, 2015. Should derivatives be privileged in bankruptcy? Journal of Finance (in press)

[12] M. Brunnermeier, L. Pedersen, 2009. Market liquidity and funding liquidity. Review of Financial Studies 22, 2201-2238

[13] S. Bougheas, A. Kirman, 2015a. Complex financial networks and systemic risk: A review. In P. Commendatore, S. Kayam, I. Kubin (eds.), Complexity and Geographical Economics: Topics and Tools. Springer, Heidelberg

[14] S. Bougheas, A. Kirman, 2015b. Systemic risk and the optimal seniority structure of banking liabilities. CFCM Working Paper 15/15, University of Nottingham

[15] R. Caballero, A. Simsek, 2013. Fire sales in a model of complexity. Journal of Finance 68, 2549-2587

[16] C. Calomiris, C. Kahn, 1991. The role of demandable debt in structuring optimal banking arrangements. American Economic Review 81, 497-513

[17] S. Cecchetti, 2008. Crisis and responses: The Federal Reserve and the financial crisis of 2007-2008. NBER Working Paper no. 14134

[18] P. Danisewicz, D. McGowan, E. Onali, K. Schaeck, 2015. Monitoring matters: Debt seniority, market discipline and bank conduct. Available at SSRN: http://dx.doi.org/10.2139/ssrn.2550866

[19] M. Dewatripont, X. Freixas, 2012. Bank resolution: Lessons from the crisis. In M. Dewatripont, X. Freixas (eds.) The Crisis Aftermath: New Regulatory Paradigms, Centre for Economic Policy Research, London, 105-143

[20] D. Diamond, 1993. Seniority and maturity of debt contracts. Journal of Financial Economics 33, 341-368

[21] D. Diamond, P. Dybvig, 1983. Bank runs, deposit insurance, and liquidity. Journal of Political Economy 91, 401-419 
[22] D. Diamond, R. Rajan, 2011. Fear of fire sales, illiquidity seeking and credit freezes. Quarterly Journal of Economics 126, 557-591

[23] L. Eisenberg, T. Noe, 2001. Systemic risk in financial systems. Management Science 47, 236-249

[24] D. Evanoff, 1993. Preferred sources of market discipline. Yale Journal of Regulation 10, 447-467

[25] D. Evanoff, L. Wall, 2002. Measures of the riskiness of banking organizations: Subordinated debt yields, risk-based capital, and examination ratings. Journal of Banking and Finance 26, 989-1009

[26] M. Flannery, S. Sorescu, 1996. Evidence of bank market discipline in subordinated debenture yields: 1983-1991. Journal of Finance 51, 1347-1377

[27] X. Freixas, J.-C. Rochet, B. Parigi, 2004. The lender of last resort: A twenty-first century approach. Journal of the European Economic Association 2, 1085-1115

[28] C. Furfine, 2001. Banks as monitors of other banks: Evidence from the overnight federal funds market. Journal of Business 74, 33-57

[29] X. Gabaix, 2011. The granular origins of aggregate fluctuations. Econometrica $79,733-772$

[30] V. Goyal, 2005. Market discipline of bank risk: Evidence from subordinated debt contracts. Journal of Financial Intermediation 14, 318-350

[31] D. Hancock, M. Kwast, 2001. Using subordinate debt to monitor bank holding companies: Is it Feasible? Journal of Financial Services Research $20,147-187$

[32] E. Hirschhorn, D. Zervos, 1990. Policies to change the priority of claimants: The case of depositor preference laws. Journal of Financial Services Research $4,111-125$

[33] O. Hart, J. Moore, 1995. Debt and seniority: An analysis of the role of hard claims in constraining management. American Economic Review 85, $567-585$

[34] R. Herring, 2004. The subordinated debt alternative to Basel II. Journal of Financial Stability 1, 137-155

[35] C. Jacklin, S. Bhattacharya, 1988. Distinguishing panics and informationbased bank runs: welfare and policy implications. Journal of Political Economy 96, 568-592

[36] J. Jordan, 2000. Depositor discipline at failing banks. New England Economic Review (March/April) 15-28 
[37] G. Kaufman, 1997. The new depositor preference act: Time inconsistency in action. Managerial Finance 23, 56-61

[38] G. Kaufamn, 2014. Too big to fail in banking: What does it mean? Journal of Financial Stability 13, 214-223

[39] N. Lenihan, 2012, Claims of depositors, subordinated creditors, senior creditors and central banks in bank resolutions. Speech delivered at the Association Européenne pour le Droit Bancaire et Financière Conference, Athens, 5-6 October

[40] S. Longhofer, J, Santos, 2000. The importance of bank seniority for relationship lending. Journal of Financial Intermediation 9, 57-89

[41] J. Marino, R. Bennett, 1999. The consequences of national depositor preference. FDIC Banking Review 12, 19-38

[42] K. Mantripragada, 1992. Depositor as a source of market discipline. Yale Journal of Regulation 9, 543-574

[43] F. Partnoy, D. Skeel, 2007. The promise and perils of credit derivatives. University of Cincinnati Law Review 75, 1019-1051

[44] E. Perotti, 2010. Systemic liquidity risk and bankruptcy exceptions. Duisenberg School of Finance Policy Paper No. 8

[45] J.-C. Rochet, J. Tirole,1996. Interbank lending and systemic risk. Journal of Money, Credit and Banking 28, 733-62

[46] A. Shleifer, R. Vishny, 1992. Liquidation values and debt capacity: A market equilibrium approach. Journal of Finance 47, 1343-1366

[47] A. Shleifer, R. Vishny, 2010. Fire sales in finance and macroeconomics. NBER Worling Paper No. 16642

[48] A. Sironi, 2003. Testing for market discipline in the European banking industry: Evidence from subordinated debt issues. Journal of Money, Credit and Banking 35, 443-472

[49] J. Thomson, 1994. The national depositor preference law. Federal Reserve Bank of Cleveland, Economic Commentary (15 February)

[50] E.-L. von Thadden, E. Berglöf, G. Roland, 2010. The design of corporate debt structure and bankruptcy. Review of Financial Studies 23, 2648-79

[51] J. Walter, 2004. Closing troubled banks: How does the process work? Federal Reserve Bank of Richmond, Economic Quarterly 90, 51-68

[52] P. Wood, 2011. The bankruptcy ladder of priorities and the inequalities of life, Hofstra Law Review 40, (1), Article 9 